\title{
A Interferência do Marketing na Construção de Padrões de Beleza
}

\section{The Interference of Marketing in the Construction of Beauty Patterns}

\author{
GEÓRGIA DOS SANTOS SIRQUEIRA (D)
}

\author{
ALMIRALVA FERRAZ GOMES (D)
}

ADLLER MOREIRA CHAVES D

\section{RESUMO}

A imagem do corpo se modifica no decorrer do tempo e a relação com o corpo e o que é considerado belo permeia a nossa sociedade desde a antiguidade. O marketing, por meio da mídia com suas peças publicitárias e propagandas, transmite padrões de beleza e comportamento e influencia diretamente a sociedade. A construção da identidade de gênero feminino é construída pela história, cultura e relações sociais que o indivíduo forma pelas experiências e vivências desde o nascer para se tornar e se reconhecer como mulher. Diante disso, pretende-se analisar como o marketing adotado por empresas do ramo de moda interfere na construção de padrões de beleza para mulheres adultas na contemporaneidade. De natureza empírica e do tipo descritivo-exploratório, optou-se pelo levantamento como técnica de pesquisa. A coleta de dados foi realizada através de questionário online e 181 mulheres na faixa etária entre 20 a 44 anos responderam ao instrumento de coleta. Ademais, houve coleta documental através das redes sociais de quatro lojas de departamento de abrangência nacional e que desenvolvem campanhas publicitárias dirigidas também ao público feminino. Os dados coletados receberam tratamento quali-quantitativo. Verificou-se que o marketing influencia a relação da mulher com a sua imagem e representação na mídia.

Palavras-chave: Consumo, Gênero, Identidade, Marketing, Mulher. 


\section{Abstract}

The body image changes over time, the relationship with the body and what is considered beautiful has permeated our society since ancient times. Marketing, through the media with its advertising pieces and advertisements, conveys standards of beauty and behavior and directly influences society. The construction of the female gender identity is built by the history, culture and social relationships that the individual forms through the experiences and experiences since birth to become and recognize themselves as a woman. Through this study, we intend to analyze how the marketing adopted by companies in the fashion industry interferes with the construction of beauty standards for adult women in contemporary times. Empirical and descriptive-exploratory, the survey was chosen. Data collection was carried out through an online questionnaire and 181 women aged 20 to 44 years answered the collection instrument. In addition, there was documentary collection through the social networks of four department stores nationwide and that develop advertising campaigns also aimed at the female audience. The collected data received quali-quantitative treatment. It was found that marketing influences the relationship of women with their image and representation in the media.

Keywords: Consumption, Genre, Identity, Marketing, Woman

\section{INTRODUÇÃO}

A imagem de como o ser humano é visto foi se modificando, com o passar dos tempos, e os padrões de beleza foram se alterando e se adequando ao período em que se encontra. O papel da mídia para divulgação desses padrões tem seu clímax de poder a partir da década de 1950 e 1960, com o surgimento da televisão e do cinema, pois a propaganda pôde alcançar diversos tipos de consumidores em lugares distintos. Nesse período, a propaganda de marcas de produtos e serviços nos canais de televisão e nos trailers de filmes alcançou o que não seria possível sem tais avanços tecnológicos. A sociedade dessas décadas começa a conhecer as novidades sobre produtos/serviços através dos comerciais, difundidos pelas mídias, em revistas, jornais, no rádio ou na televisão (PIZZINATO; AEVEDO, 2010). 
A relação construída entre a imagem que é produzida e reproduzida pela mídia tem no marketing, portanto, seu auxiliar na construção de peças publicitárias para convencer o consumidor de que determinado produto/serviço será adequado para cada indivíduo, fazendo com que ele se identifique com o que lhe é apresentado. Assim, muitas vezes, o sujeito se adequa ao que é convencionado pela sociedade como ideal.

As primeiras teorias de marketing apoiaram-se em concepções econômicas. Nesse ínterim, as ações de marketing eram voltadas apenas para o lucro sem se importar com a diversificação ou a individualização dos produtos para os consumidores. Esse pensamento foi se modificando e o marketing passou a utilizar-se de estratégias para influenciar a sociedade e os consumidores. As ações de marketing eram realizadas, então, para despertar necessidades e desejos nos consumidores em adquirir determinado produto e/ou serviço, mesmo sem necessidade. Para tanto, o marketing passou a fazer uso de estratégias para conhecer o mercado, verificar a aceitação de produto/serviço e, após essa análise, segmentar o mercado, levando em conta gênero, faixa etária, renda, dentre outros fatores. Tal segmentação determina onde tal produto/serviço será aceito e se há possibilidade de sucesso da sua inserção no mercado. Com isso, as ações são potencialmente voltadas para apresentação do produto/ serviço para a sociedade através da propaganda veiculada nos diversos meios de comunicação disponíveis (MARCON; MARCON; ROCHA, 2017).

Deste modo, o marketing desempenha importante papel na construção de padrões de beleza, sobretudo, feminino, pois atua na propagação desses padrões através de suas ações. Segundo Vianna (2005), a sociedade aceita a imposição de um padrão de beleza tido como o mais "bonito" visualmente. Atualmente, este padrão, para as mulheres, seria o modelo de beleza europeu: mulher alta, magra, cabelos compridos, lisos e loiros, bastante destoante das mulheres originalmente brasileiras, embora já se veja algumas campanhas publicitárias distintas desse padrão. O modelo de mulher brasileira parece não se encaixar nesse padrão em função da mestiçagem, ou seja, temos diversos tipos de corpo, cada um bonito à sua maneira, mas que não se assemelham aos padrões impostos pela mídia. 
Há uma disparidade entre o modelo de beleza divulgado pela mídia e a realidade e muitas mulheres sofrem para se enquadrar no padrão proposto, pois o biotipo da mulher brasileira é bastante diferente daquele difundido pela mídia. Para Vianna (2005), querer que todas as mulheres se enquadrem no padrão de beleza imposto, sem levar em consideração que todas têm corpos distintos, é uma forma de violência. Ser magra, ter cabelos alisados (mesmo que natural), manter unhas compridas, usar salto alto o dia inteiro e estar sempre sorrindo, porque, pura e simplesmente, são mulheres pode ser uma forma de agressão.

Em suma, vive-se em uma sociedade patriarcal, machista e desigual, apesar de todos os avanços em busca de igualdade. A mulher luta diariamente pela construção de seu papel como protagonista na história e da sua história. A mulher moderna assume várias identidades e desempenha diversos papéis ao longo de sua vida, ao ser mulher, filha, mãe, esposa, trabalhadora, avó, estudante, etc. Em vista disso, enfrenta inúmeros desafios cotidianamente. Diante do exposto, este artigo tem o objetivo de analisar como o marketing adotado por empresas do ramo de moda interfere para construção de padrões de beleza para mulheres adultas na contemporaneidade. Para tanto, o presente artigo, em sua revisão de literatura, intentará estabelecer um diálogo teórico entre marketing e gênero. Para alcançar tal intento, inicialmente, discutir-se-á questões de gênero e identidade, posteriormente, marketing e consumo e, por fim, construção da imagem do feminino. Após tal debate teórico, apresentar-se-á os procedimentos metodológicos da pesquisa e analisar-se-á à luz do referencial teórico os dados coletados em campo para enfim apresentar as considerações finais do estudo.

\section{GÊNERO E MARKETING: DIÁLOGOS}

\section{Identidades e Gênero}

O debate em torno de identidade e gênero carece, inicialmente, da compreensão do conceito de identidade, gênero, identidade de gênero, construção da imagem feminina e desigualdades de gênero. Assim, pode-se entender como se constrói a concepção de identi- 
dade do gênero feminino e qual o seu papel na construção do ser feminino, no ser mulher.

Identidade, segundo dicionário da língua portuguesa, significa: 1. Qualidade de idêntico. 2. Conjunto de traços que distinguem um indivíduo dos demais (ROCHA; PIRES, 2005). O significado da palavra está correto, todavia, a construção da identidade do ser humano perpassa por toda a sua vida. Somos o que podemos conceituar como a construção de várias experiências e de várias vivências que nos transformam e nos moldam a ser um indivíduo único repleto de peculiaridades (ZAMBONI, 2013).

"A identidade é uma construção sócio histórica, constantemente transformada na interação com o outro" (CAIXETA, 2004, p. 214). Partindo desse pressuposto, o indivíduo não nasce com a sua identidade pronta e acabada. Ela se constrói de acordo com a cultura em que está inserido, raça, etnia, classe social e o gênero ao qual se identifica. Para Berger e Luckmann (2004), a pessoa não pertence a sociedade ao nascer, mas passa a integrá-la a partir de seu desenvolvimento, desde a primeira infância - fase primária, quando internaliza as informações do mundo onde está inserido (seus pais, seus irmãos, seus avós, seus primos, etc.) - até a fase secundária, na qual o indivíduo internaliza os mundos em que faz parte no decorrer da sua vida.

A concepção de gênero, diferentemente do sexo biológico, nasce com o feminismo, que busca, dentre outras coisas, igualdade de direitos entre mulheres e homens. O gênero, dessa maneira, é construído histórico e socialmente e nos é transmitido pela educação, cultura, meios de comunicação e no ambiente que estamos inseridos. Em outros termos, independentemente do sexo biológico que se nasce, mesmo que haja a identificação com o sexo ao qual se nasce, há uma construção como indivíduo, feminino ou masculino, de acordo com o que é absorvido das experiências de vida. Ou seja, uma construção social marcada por vivências, pelo que o outro transmite e pelo que se consegue compreender como parte de nós (LOURO, 1997; ZAMBONI, 2013; MARCON; MARCON; ROCHA, 2017; SANT'ANA; BISPO, 2017).

Assim como a construção de identidade e de gênero, a identidade de gênero é, do mesmo modo, uma construção social, cultural 
e histórica. A conceituação de identidade de gênero começa a ser construída junto com o movimento feminista, especificamente na década de 1990, na terceira fase do movimento (LOURO, 1997). Os seres humanos são plurais e, como tal, não podem ser definidos de um só modo. Da mesma maneira, a identidade de gênero e sexual são distintas, uma vez que um sujeito pode se identificar como sendo do gênero feminino e na sua certidão de nascimento, por exemplo, ser do sexo masculino e ter atração sexual por mulheres, pois "[...] a sexualidade não se define apenas por características biológicas, mas resulta também de aspectos psicológicos e interações com o contexto familiar e social" (SANT'ANA; BISPO, 2017, p. 21). Ou seja, somos uma composição do meio ao qual estamos inseridos, uma construção familiar, social e cultural, baseada em todas as experiências vividas.

A construção da identidade feminina é histórica e leva em conta a família, a cultura e a sociedade que a mulher se encontra. Partindo da célebre frase de Simone de Beauvoir (1980, p. 9), “Ninguém nasce mulher: torna-se mulher", tanto a mulher quanto o homem constroem a sua identidade no decorrer da vida. A mulher nasce com sexo biológico feminino, mas só depois de se conhecer que se identifica como tal, como mulher de fato. Todavia, as imposições patriarcais e machistas da sociedade, a qual estamos inseridos, impõem à mulher um modelo ideal a seguir. Tal modelo ideal seria a mulher submissa, pura, sem emitir opinião e não questionar o que lhe é designado a fazer. Esse modelo ideal de mulher existe apenas na imaginação de muitos homens. A realidade é que, potencialmente, toda mulher quer ser responsável pela sua própria vida sem intervenções.

Para se identificar com o ser mulher, inúmeros fatores devem ser levados em consideração. A mulher na medida em que se enxerga e se reconhece como mulher constrói a sua identidade feminina. A construção da identidade feminina é social e tem influência da sociedade e da cultura que o sujeito faz parte. Para Sant'ana e Bispo (2017), “[...] a definição das identidades sociais, seja relativa ao gênero, à sexualidade, à raça ou nacionalidade são constituídas a partir do contexto cultural e histórico no qual o sujeito está inserido, e é nessa junção das variadas e distintas identidades e circunstâncias que o sujeito se reconhece e se define" (2017, p. 22). Em suma, o 
constructo do que significa identidade feminina parte das relações estabelecidas pelo significado pessoal que estabelecemos e por questões culturais.

"A humanidade é extremamente diversa. Não só nas características pessoais, individuais, mas fundamentalmente, diversa no modo através do qual cada indivíduo 'vê', 'enxerga' o outro e a si próprio", ao tratar de desigualdade social (SANTOS, 2006, p. 2). Em diversas publicações, é recorrente a abordagem sobre o tema desigualdade de gênero. Tal tema é de grande relevância e deve ser objeto de estudo da academia, mas, sobretudo, da sociedade, pois, em especial as mulheres ainda sofrem, e muito, com as desigualdades advindas do gênero ao qual se identificam. Vale salientar que o presente trabalho tratará de gênero feminino como mulher e gênero masculino como homem.

A desigualdade entre a mulher e o homem não começou no século XXI e perdura no decorrer da história da humanidade. Em diversos episódios, seja na literatura, através de relatos históricos, ou em nosso cotidiano, lemos, vivenciamos, presenciamos, escutamos ou somos vítimas, em algum momento de nossas vidas, das desigualdades impostas pelo gênero, pois é algo, infelizmente, costumeiro. O simples fato de se identificar como mulher a coloca em situação de vulnerabilidade em relação ao homem, visto que esse se considera superior e dominante em relação a mulher (BARBOZA; ALMEIDA JÚNIOR, 2017).

A questão da desigualdade começou a ser amplamente debatida nas discussões do movimento feminista, durante as três ondas. A relação de desigualdade entre os gêneros existe como se o homem fosse superior a mulher, pois o homem é visto como o ser dominante da relação e a mulher lhe deve submissão e subserviência por ser considerada frágil, sensível e incapaz para tomar suas próprias decisões (CABRAL; DÍAZ, 1998). Para Louro (1997), a dominação do homem encontrou, em algumas teorias, explicações que justificam a distinção entre os gêneros. Uma dessas teorias seria a biológica:

Relacionada, a princípio, às distinções biológicas, a diferença entre os gêneros serviu para explicar e justificar as mais variadas distinções entre mulheres e homens. Teorias foram construídas e utilizadas para 
"provar" distinções físicas, psíquicas, comportamentais; para indicar diferentes habilidades sociais, talentos ou aptidões; para justificar os lugares sociais, as possibilidades e os destinos "próprios" de cada gênero. O movimento feminista vai, então, se ocupar centralmente dessa diferença - e de suas conseqüências (LOURO, 1997, p. 45).

Costa (1998) aponta que as feministas fizeram uso do conceito de gênero para expor as relações desiguais entre os sexos. Todavia, o que buscavam era se afastar da visão biológica que pairava todas as explicações sobre a subordinação feminina. "As mulheres sabem que não são iguais aos homens, visto que não são idênticos, o que procuram é que sejam equivalentes, respeitando as suas diferenças" (LOURO, 1997, p. 46).

Para Cabral e Díaz (1998), os papéis atribuídos à mulher e ao homem são construídos pela cultura e pela sociedade que estão inseridos. Tais papéis começam a ser construídos desde o ventre materno, onde tudo começa a ser preparado para a chegada do bebê de acordo com o sexo biológico, desde a escolha das cores para o enxoval e para as paredes do quarto (rosa se for menina, azul se for menino), até o nome, os brinquedos, etc. Deste modo, o recém-nascido, enquanto indivíduo, será identificado e ensinado pelos pais, família, escola, etc., pelo sexo de seu nascimento, e deseja-se que esse indivíduo se comporte de acordo com o que é esperado da sua genitália.

A desigualdade entre a mulher e o homem começa então desde seu nascimento e se perpetua ao longo da vida. É evidente essa relação de desigualdade nos mais diversos âmbitos, seja familiar ou social. O papel social do homem é no meio público, portanto, à mulher cabe, seguindo essa concepção, a esfera privada. Então, dentro das famílias, cabe ao homem prover o lar, por isso é chamado de chefe da casa, e à mulher a sua organização, isto é, a cuidadora do marido, dos filhos e da casa, sendo chamada de dona de casa (SANTOS, 2006; BORGES, 2013).

Mas esse acúmulo de funções causa exaustão e sobrecarga na mulher, uma vez que, além de desempenhar o papel de trabalhadora, ela tem, ainda, as atividades domésticas diárias para dar conta, já que, na maior parte dos lares, tais atividades domésticas são realizadas pela mulher sozinha, sem o auxílio e colaboração do 
companheiro, esposo ou filhos. O trabalho doméstico é tido como atividades exclusivamente femininas, deste modo, as atividades são repassadas apenas para as filhas, os filhos - por serem homens - não desempenham tais funções dentro de casa. A mulher tem, portanto, empregos formais e informais, dentro e fora de casa: “[...] a dupla ou tripla jornada feminina é um dos elementos centrais da desigualdade de gênero entre atividades produtivas e reprodutivas" (ALVES; CAVENAGUI, 2013, p. 99).

A figura da mulher está atrelada então ao cuidado com o outro, como se esse fosse o seu único papel dentro da sociedade: "[...] cuidado envolve a criação dos filhos, a guarda das crianças, a atenção com os parentes idosos ou com necessidades especiais, as atividades de educação, saúde e dos afazeres domésticos, assim como a convivência das pessoas que cuidam umas das outras e do ambiente natural" (ALVES; CAVENAGUI, 2013, p. 100). Na execução de atividades domésticas e de atividades remuneradas que são tidas como "femininas", como é caso das professoras de educação infantil, são vistas como "tias". Essas profissões são, na maioria das vezes, consideradas como extensões da família e a docente não é vista como educadora, como de fato é. Os espaços "destinados" aos homens são mais variados, todavia, o trabalho doméstico não está entre eles.

A Constituição da República Federativa do Brasil (1988), em seu artigo 5요 § 1, diz que "homens e mulheres são iguais em direitos e obrigações". Portanto, subentende-se que não haveria desigualdades entre mulheres e homens, porém, não é o que se verifica na sociedade atual. Há uma discrepância entre a legislação e os hábitos da nossa cultura e sociedade. Se as leis fossem colocadas em prática não teríamos esse abismo desigual entre mulheres e homens.

Embora haja um aparato legal, tanto nacional quanto internacional, proposto em Tratados Internacionais e dispostos pela ONU, fica evidente que temos um caminho muito grande a percorrer no tocante a diminuição das desigualdades entre os gêneros.

\section{Marketing e Consumo}

O marketing está presente em vários momentos das nossas vidas e do nosso dia a dia, ao apresentar conceitos dos mais diversos temas e levar o consumidor a conhecer produtos/serviços, tais como 
moda, padrões de beleza, comportamento, consumo, dentre outros. Ademais, influencia a sociedade a utilizar produtos/serviços e adotar padrões construídos como sendo o mais adequado (KOTLER; ARMSTRONG, 2007).

O marketing deve estimular o consumo. Esse é o seu papel dentro das empresas de produção de bens e/ou serviços, tendo em vista que deve administrar as demandas e necessidades e desejos dos consumidores (COBRA, 2009). O marketing é voltado para que o cliente consuma mesmo que não necessite do produto e/ou serviço. Desse modo, atendendo suas expectativas e anseios quanto ao produto/serviço que se pretende adquirir. Segundo Limeira (2008, p. 7), "[...] o consumo é definido como ato ou efeito de consumir, ou seja, o comportamento de escolha, compra, uso e descarte de produtos e serviços para a satisfação de necessidades e desejos humanos".

Embora a mulher represente a maioria da população brasileira e constitua um nicho de mercado, é considerada como minoria, da mesma forma que os homossexuais, deficientes físicos, pois, as peças publicitárias ou as propagandas não representam a mulher real, do mesmo modo que pouco ou nada se vê de propagandas voltadas para deficientes físicos ou idosos. Consequentemente, faz-se necessário uma maior representatividade dessas minorias dentro do marketing e das ações voltadas para esses públicos que, por vezes, são esquecidos (SAJI, 2005; GARCIA, 2009, 2019; MORAES et al., 2014, CAVALCANTI et al., 2016).

Vivemos em um mundo diversificado, consequentemente, devemos buscar formas efetivas para a inclusão de todos os grupos que compõem nossa sociedade, dirimir a intolerância e aceitar que todos os seres são únicos e diversos, independentemente de seu gênero, orientação sexual e raça. Diante do exposto, o marketing tem que fazer a sua parte para que as mudanças ocorram dentro das organizações e que impactem positivamente a sociedade. Os indivíduos precisam se sentir representados e incluídos nas peças e companhas publicitárias, dessa forma, haverá, de fato, a representatividade de todos os sujeitos. Afinal, “[...] compreender e aceitar a diversidade é fundamental para proporcionar a todos o livre acesso ao consumo e o tratamento igualitário" (CAVALCANTI et al., 2016, p. 204). 


\section{Construção da Imagem do Feminino}

A construção da imagem do feminino passa por modificações no decorrer da história. Da mesma maneira, a moda, os padrões de beleza e estéticos acabam ditando como a mulher deve se apresentar na sociedade. Segundo Machado e Pereira (2010), “[...] a mulher, historicamente, tem o seu papel associado à maternidade e à fertilidade" (2010, p. 2). Tal concepção se deve ao fato de que historicamente a mulher esteve restrita ao espaço privado. Diante disso, será abordado, nesta seção, o conceito de beleza, seu significado, bem como a influência do marketing com relação aos padrões de beleza e a representação da imagem da mulher na mídia.

O conceito de beleza é subjetivo, portanto, cada pessoa tem sua definição do que considera belo. No entanto, tal conceito se modifica no decorrer dos séculos, conforme a sociedade e a cultura que os indivíduos estão inseridos. Cada pessoa tem a sua concepção do que considera belo ou feio no outro, que, por sua vez, é influenciada pelo meio. De acordo com Dourado et al. (2018), a beleza depende da visão de mundo do indivíduo, que é construída através das experiências adquiridas no decorrer da vida e sofre interferência da sociedade e cultura da qual o sujeito está inserido.

A beleza dos corpos é estabelecida segundo os padrões de cada época (DOURADO et al., 2018). Assim, pode-se verificar em livros, revistas e demais publicações, das mais diferentes épocas, que o padrão dos corpos foi se modificando. “O padrão de beleza feminina foi mudando de acordo com as épocas por diversos fatores, mas uma coisa é certa: desde a antiguidade, o corpo da mulher é descrito em normas e padrões" (AGUILERA; BRANCO; PRADO, 2016, p. 1).

No século $X X$, o ideal de um corpo magro ganha força, como sinônimo de saúde e beleza: “Veicula-se a representação da beleza estética associada a determinados ideais de saúde, magreza e atitude" (BARBOSA; MATOS; COSTA, 2011, p. 29). O padrão de beleza atual é outro. É imposto ao indivíduo, em especial às mulheres, que se adaptem ao que foi estabelecido como "arquétipo", para se enquadrarem na sociedade e nos seus grupos sociais. "Assim, há uma construção cultural do corpo, com uma valorização de certos atributos e comportamentos em detrimentos de outros, fazendo com que haja um corpo típico para cada sociedade" (SAUERBRONM; 
TONINI; LODI, 2011, p. 6). O corpo é construído pelo indivíduo, utilizando-o para se comunicar e se posicionar na sociedade (MACHADO; PEREIRA, 2010).

Naomi Wolf (1992), em seu livro O Mito da Beleza, trata a beleza como um mito. Esse mito da beleza não é criado pelas mulheres, outro sim, pela sociedade patriarcal e o poder masculino busca impor à mulher o que é belo. "A 'beleza' é um sistema monetário semelhante ao padrão ouro. Como qualquer, sistema, ele é determinado pela política e, na era moderna no mundo ocidental, consiste no último e melhor conjunto de crenças a manter intacto o domínio masculino" (WOLF, 1992, p. 15). Além disso, “[...] quanto mais numerosos foram os obstáculos legais e materiais vencidos pelas mulheres, mais rígidas, pesadas e cruéis foram as imagens da beleza feminina a nós impostas" (WOLF, 1992, p. 11). Assim, Wolf (1992) deixa claro que as mulheres devem sempre lutar contra o estereótipo tido como feminino e contra a dominação masculina, uma vez que, “[...] à medida que as mulheres se liberaram da mística feminina da domesticidade, o mito da beleza invadiu esse terreno perdido, expandindo-se enquanto a mística definhava, para assumir sua tarefa de controle social" (WOLF, 1992, p. 12-13).

Por fim, a concepção e significado de beleza e os padrões estabelecidos são construções da cultura de determinada sociedade ao qual o indivíduo faz parte. Todavia, fica evidente que como se faz parte de uma sociedade queremos nos encaixar nela e no grupo do qual fazemos parte. Machado e Pereira (2010) apontam que a beleza “[...] é vista como responsabilidade da mulher e não seguir os padrões estéticos vigentes seria ir contra a norma social imposta para as mulheres" (MACHADO; PEREIRA, 2010, p. 7). Desse modo, aceitamos as imposições sociais para nos sentirmos parte do todo e sermos aceitos.

O marketing influencia o consumo e as relações sociais. Inicialmente, a criação de padrões sofreu influência da mídia impressa. A partir das décadas de 1950 e 1960, com a chegada da TV e do cinema, a mídia conseguiu alcançar um maior número de espectadores e potenciais consumidores (PIZZINATO; ACEVEDO, 2010) e passou a influenciar não só o que comemos, mas o que vestimos. Segundo Fiorani (2007), o marketing é “[...] um dos mais fortes operadores 
de controle social" (2007, p. 22). Deste modo, podemos dizer que o marketing atua diretamente sobre a cultura, na sociedade e nos padrões de beleza existentes e, ainda, naqueles que serão construídos, pois, a mídia divulga o que deve ser consumido: “Assim, o corpo é algo que o indivíduo constrói que comunica quem ele é e o posiciona na sociedade, sendo um objeto de valor a ser consumido" (MACHADO; PEREIRA, 2010, p. 2).

Conforme Castro e Prado (2012), a evolução dos meios de comunicação "[...] trouxe profundas transformações no modo como os sujeitos entendem as relações sociais e com isso transformou a natureza da produção e circulação das formas simbólicas - expressões linguísticas, gestos, ações, obras de arte, etc. - no mundo moderno" (2012, p. 241-242). O desenvolvimento do marketing está atrelado ao desenvolvimento dos meios de comunicação. A contar da segunda metade do século XX, seu crescimento foi notório.

Do mesmo modo que o marketing influencia o que se compra ou se veste, a sociedade, nos vários períodos da história, interferiu e interfere na relação do indivíduo com seu corpo. Para Castro (2001, p. 87), "[...] a preocupação com a beleza do corpo ganha força no decorrer do século. Na contemporaneidade, presenciamos a tendência à supervalorização da aparência corporal, que leva os indivíduos a uma busca frenética pela forma e volume corporais ideais".

Para compreender como se concebe a representação e imagem feminina, precisamos entender o significado de representação e imagem na construção da identidade feminina. Barros (2005) conceitua imagem como uma construção e, do mesmo modo que a identidade, somos uma composição de experiências e vivências que todo indivíduo perpassa no decorrer de sua vida. Percebemos nosso corpo aos poucos através da curiosidade, junto com o corpo do outro, dessa forma, não se sabe se observamos o nosso corpo primeiro e depois o do outro ou vice-e-versa.

A representação é a construção de conceitos aprendidos das relações históricas, sociais e culturais. Os indivíduos são, de fato, a composição de vários conceitos, que são incutidos através das relações que desenvolvemos com o outro, com o mundo e como somos vistos depois que estamos "construídos". A identidade feminina é uma construção social e cultural. Destarte, a sua representação na 
mídia também tem relação direta de como a mulher se sente representada e como é construída a sua imagem através da mídia. São vários os padrões e imagens de beleza impostos como ideais: "A mídia representa na contemporaneidade um instrumento importante para transmissão de mensagens sobre padrões de comportamento e imagens de beleza considerados ideais" (SALES et al., 2014, p. 5).

De acordo com Zamboni (2013), muitas são “[...] as representações femininas repetidas e redistribuídas para a sociedade" (2013, p. 54). Essa representação gira em torno dos papéis assumidos pela mulher e das identidades femininas construídas por ela, no decorrer de sua vida, como mulher, filha, mãe, esposa, trabalhadora, dentre outras.

Segundo Castro e Prado (2012), as construções de alguns padrões giram em torno do inalcançável pelo ser humano, como o padrão estabelecido para as modelos ou, como citado pelas autoras, o da boneca Barbie, que se fosse humana teria um corpo quase que impossível de se alcançar pelas mulheres reais. "Além deste aspecto impositivo, no caso do corpo feminino, é importante percebermos o quanto a publicidade, principalmente, instrumentaliza o corpo feminino, transformando-o em objeto para conquistar a atenção do consumidor para seus produtos" (CASTRO; PRADO, 2012, p. 249-250).

A representação de corpo ideal e o padrão socialmente aceito e propagado pela mídia é a mulher branca, alta, magra, cabelos longos e lisos (CASTRO, 2004; SIQUEIRA; FARIA, 2007; MACHADO; PEREIRA, 2010; CASTRO; PRADO, 2012; HEINZELMAN et al., 2012;). Esse padrão estético é propagado como sendo o padrão ideal e que todas as mulheres devem seguir. Mas, tal padrão não leva em consideração as peculiaridades e individualidades das mulheres. Em se tratando das mulheres brasileiras, esse padrão é praticamente inatingível, pois com a miscigenação das raças, encontrar uma mulher, nos padrões pré-estabelecidos, é bastante improvável.

A mídia continua a conceber, incorporar e construir discursos sobre as identidades, utilizando a separação por gênero, através de estereótipos (CASTRO; PRADO, 2012). Deste modo, apesar da luta por direitos travada pelas mulheres desde a primeira onda do movimento feminista (no início do século XX) até os dias atuais, ainda há a concepção de gênero como binário, ou seja, feminino/masculino. 
Partindo da visão de Zamboni (2013), podemos conceber que os padrões pré-estabelecidos pelos meios de comunicação influenciam diretamente o modo como as mulheres são representadas e promovem a distorção da imagem da mulher propagada pela mídia. Hoje, o uso das mídias sociais colabora para a exibição dos corpos perfeitos - perfeitos para os padrões de beleza cultuados pela mídia, mesmo que para isso seja utilizado intervenção cirúrgica, uso de produtos de beleza e maquiagem, suplementos alimentares, etc.

\section{Procedimentos metodológicos}

A metodologia empregada na presente pesquisa leva em consideração o objetivo do trabalho, portanto, classifica-se como empírica, tendo em vista que intentou "[...] traduzir os resultados em dimensões mensuráveis" (DEMO, 1985, p. 25). Quanto aos objetivos, é do tipo descritivo-exploratória, uma vez que buscou "[...] proporcionar maior familiaridade com o problema, com vistas a torna-lo mais explícito ou a constituir hipóteses" e descrever as "[...] características de determinada população ou fenômeno ou, então, o estabelecimento de relações entre variáveis" (GIL, 2002, p. 42). A técnica utilizada neste estudo foi o levantamento, que se caracteriza pela consulta direta às pessoas cujo comportamento se deseja conhecer (GIL, 2002; 2008). Ademais, com a finalidade de compreender melhor o fenômeno estudado, optou-se pela pesquisa documental eletrônica de primeira mão, uma vez que as fotografias compartilhadas nas páginas da rede social das lojas de departamento C\&A, Marisa, Renner e Riachuelo no Instagram ainda não tinham recebido nenhum tratamento analítico que tenha sido oficialmente publicado.

O universo desta pesquisa foi composto por mulheres jovens, na faixa etária de 20 a 44 anos. O estudo iniciou-se com mulheres jovens residentes da cidade de Vitória da Conquista e atingiu mulheres, na referida faixa etária, de cidades da região Sul e Sudoeste da Bahia e cidades de diversos estados do Brasil. Tal recorte etário se deve a propensão maior pelo consumo de artigos de moda, considerando-se os objetivos da pesquisa e levando em conta que, em tese, as mulheres, nessa faixa etária, possuem trabalho remunerado e são independentes para escolher os produtos que deseja consumir. A escolha da técnica de amostragem snowball permitiu, 
portanto, que se alcançasse mulheres em diversas localidades do Brasil e se chegasse a uma amostra de amostra de 181 (cento e oitenta e uma) mulheres, que responderam ao instrumento de coleta. Vale salientar que na amostragem bola de neve (snowball), “[...] um sujeito escolhido de forma intencional ou de acordo a conveniência do pesquisador indica outro sujeito para integrar a amostra" (APPOLINÁRIO, 2012, p. 134).

Em se tratando do instrumento de coleta, optou-se pela aplicação de questionário como meio para obter os dados necessários para responder às questões elencadas nos objetivos. Foi adotado o Google Formulários, uma vez que ele se apresentou como uma ferramenta adequada para aplicação dos questionários e alcance de um maior número de pessoas.

A pesquisa foi realizada em duas fases. Na primeira fase, aplicaram-se o questionário. Na segunda fase, foi empregada a captura de peças publicitárias divulgadas na rede social, Instagram, das lojas de departamento C\&A, Marisa, Renner e Riachuelo, durante os períodos de 17 de fevereiro a 22 de março e de 22 de outubro a 09 de novembro de 2020, a fim de se obter mais dados e compreender melhor o fenômeno estudado, uma vez que tais lojas desenvolvem uma intensa campanha publicitária dirigida ao público feminino e estão presentes não só na cidade de Vitória da Conquista, mas em todo o território nacional, principalmente, nas cidades de médio e grande porte. Ademais, além de desenvolverem intensas campanhas publicitárias veiculadas em outdoor e televisão, realizam vendas pela internet, portanto, a maioria das mulheres da faixa etária pesquisada as conhece e, inclusive, já consumiu algum produto da marca.

Quanto ao tratamento, a presente pesquisa se enquadra como mista, uma vez que adotou os dois tipos de análise nos dados coletados. O tratamento quantitativo adotou a tabulação eletrônica, "uma vez que facilita, ao leitor, a compreensão e interpretação rápida da massa de dados, podendo, apenas com uma olhada, apreender importantes detalhes e relações" (LAKATOS; MARCONI, 2003, p. 169). Assim, as ferramentas do Excel e do SPSS (Statistical Packages for the Social Sciences) foram aplicadas para facilitar a visualização dos dados, através de representações e gráficos facilitando a análise dos dados obtidos. O conteúdo das peças publicitárias recebeu 
tratamento qualitativo, no tocante ao aspecto da interpretação dos dados, conforme apontam Vieira e Rivera (2012).

\section{ANÁliSE E DISCUSSÃo DOS DADOS}

Esta seção se propõe a discutir os resultados obtidos pela aplicação dos questionários com as participantes do estudo e a análise das peças publicitárias colhidas em imagens publicadas nos stories do Instagram. A escolha desta rede social se deve ao fato de as publicações serem feitas diariamente e por estarem sendo mais utilizadas pelas lojas para divulgação de suas propagandas e peças publicitárias das lojas de departamentos C\&A, Marisa, Renner e Riachuelo. Conforme descrito na metodologia, o questionário foi elaborado e enviado pelo Google Formulários, para diversas mulheres, adotando a técnica de amostragem snowball, que poderiam compor a amostra ou encaminhar para outras que pudessem respondê-lo.

Foi analisado um total de 181 questionários, respondidos por mulheres entre 20 e 44 anos, residentes ou não da cidade de Vitória da Conquista. Grande parte das respondentes encontra-se na faixa etária de 20 a 25 anos (39,23\%), 32,04\% das mulheres têm entre 36 e 44 anos, 16,02\% estão na faixa etária de 26 a 30 anos e, por último, $12,71 \%$ das participantes possuem de 31 a 35 anos. Quanto à etnia, $44,75 \%$ se declaram parda, 32,6\% branca, 18,23\% negras, indígenas, amarelas e $5 \%$ marcaram a opção outras. Com relação ao grau de escolaridade, a maioria tem ensino superior incompleto $(34,81 \%)$, ensino superior completo $(22,65 \%)$ ou pós-graduação $(34,25 \%)$. Ensino médio completo, ensino médio incompleto e ensino fundamental incompleto somam juntos $8,9 \%$ das respostas. A amostra nos mostra que a maioria das participantes possui nível superior incompleto, superior completo ou pós-graduação. Dessa forma, em se tratando do grau de instrução, a amostra da pesquisa é mais homogênea, o que pode interferir na percepção das mulheres. $\mathrm{O}$ estado civil revela que mais da metade das participantes é solteira $(59,12 \%)$, casadas e em união estável somam $36,47 \%$. Viúvas e divorciadas ficam com $4,42 \%$ das respostas. Quanto ao local de moradia, $76,22 \%$ residem na zona urbana da cidade de Vitória da Conquista e 2,76\% na Zona Rural de Vitória da Conquista. Aquelas que moram em outras cidades totalizam 20,99\% da amostra. A maioria das participantes $(63,54 \%)$ 
não possui filhos, 23,76\% têm de um a dois filhos, 10,5\% possuem entre três e quatro filhos e apenas 2,21\% têm acima de cinco filhos.

Após essa breve descrição do perfil socioeconômico das participantes, as próximas seções irão tratar da relação entre o marketing e universo feminino e discutir a questão da imagem e da beleza feminina.

\section{O Marketing e o Universo Feminino}

Este tópico pretende analisar as ações de marketing voltadas para o público feminino. Para tanto, será apresentada a percepção das mulheres a respeito do tema e peças publicitárias publicadas no Instagram das lojas de departamento C\&A, Marisa, Renner e Riachuelo. Ademais, pretende verificar de que modo o marketing institucional influencia a representação da mulher na sociedade.

A mulher não nasce mulher apenas por conta do sexo biológico constatado ao nascimento, a mulher se torna e se reconhece mulher ao longo se sua vida, com as experiências vividas. A construção da identidade de gênero feminino está relacionada a aspectos históricos, culturais e sociais, perpassando as várias fases da vida da mulher, até que ela se identifique como mulher. Por isso, pressupõe-se que as campanhas publicitárias das empresas de alguma forma influenciam a construção do ser mulher. Diante disso, levantou-se uma série de indagações às mulheres que serão tratadas neste tópico.

Boa parte das mulheres $(43,65 \%)$ se sente indiferente em relação as propagandas de moda vinculadas pela mídia. No entanto, 37,57\% sentem-se desconfortáveis. Para compreender melhor tal sentimento, cruzou-se tal resultado com a faixa etária das participantes (Tabela 1). Ao se cruzar esse dado com a idade, é possível verificar que o desconforto está concentrado entre as mais jovens da amostra. 
Tabela 1: Relação entre Faixa etária e Sentimento desencadeado com as propagandas de moda feminina na mídia

\begin{tabular}{|c|c|c|c|c|c|}
\hline \multirow{2}{*}{\multicolumn{2}{|c|}{ Desconfortável }} & \multicolumn{3}{|c|}{$\begin{array}{l}\text { Sentimento desencadeado com as propa- } \\
\text { gandas de moda feminina na mídia }\end{array}$} & \multirow{3}{*}{$\begin{array}{l}\text { Total } \\
39,22\end{array}$} \\
\hline & & \multirow{2}{*}{\begin{tabular}{|l|} 
Confortável \\
15,47
\end{tabular}} & \multirow{2}{*}{$\begin{array}{l}\text { Indiferente } \\
7,73\end{array}$} & \multirow[b]{2}{*}{16,02} & \\
\hline \multirow{5}{*}{$\begin{array}{l}\text { Faixa } \\
\text { etária }\end{array}$} & $\begin{array}{l}20 \text { a } 25 \\
\text { anos }\end{array}$ & & & & \\
\hline & $\begin{array}{l}26 \text { a } 30 \\
\text { anos }\end{array}$ & 4,98 & 2,21 & 8,84 & 16,03 \\
\hline & $\begin{array}{l}31 \text { a } 35 \\
\text { anos }\end{array}$ & 6,62 & 1,65 & 4,42 & 12,71 \\
\hline & $\begin{array}{l}36 \text { a } 44 \\
\text { anos }\end{array}$ & 10,50 & 7,18 & 14,36 & 32,04 \\
\hline & Total & 37,57 & 18,78 & 43,65 & 100 \\
\hline
\end{tabular}

Fonte: Pesquisa de campo, 2020.

Os dados da Tabela 1 revelam que as propagandas de moda feminina causam um desconforto maior nas mulheres mais jovens. É possível inferir com isso que o acesso prematuro aos meios de comunicação e internet disponível afete mais intensamente as mulheres mais jovens, tendo em vista que estão mais expostas a tais tecnologias. Hoje, as mulheres conseguem ter voz, dessa forma, podem se expressar mais e melhor e dizer o que lhes agrada ou não, o que era bastante raro há pouco mais de 50 anos. Segundo Vianna (2005), a mídia e a publicidade reforçam valores e discursos sobre a mulher. Tais valores e discursos refletem características de uma sociedade sexista e misógina, advindas do Estado e da Igreja. Desta maneira, a mulher é vista como propriedade e objeto do homem, algo que pode ser exposto como um troféu. Por esta razão, vemos ainda muitas peças publicitárias que expõe o corpo feminino como mercadoria. As mulheres mais jovens têm a oportunidade de criticar e se posicionar acerca do tipo de publicidade que estão expostas mais do que as mulheres mais maduras, que de um modo geral reproduzem uma educação machista.

De um total de 181 mulheres, $45,86 \%$ das respondentes afirmam que nunca ou raramente se sentem representadas nas propagan- 
das de roupa feminina que são divulgadas na televisão, internet e mídias sociais. A percepção das mulheres e as peças publicitárias apresentadas (Figura 1) confirmam que o marketing dessas empresas, muito embora considerem o gênero do cliente (CASTRO; PRADO, 2012), ainda divulgam padrões e estereótipos de modelos para divulgar suas coleções de roupas. Quando questionadas se se sentem representadas nas propagandas de roupa feminina, 43,1\% das mulheres dizem que apenas às vezes são contempladas nas propagandas (Tabela 2).

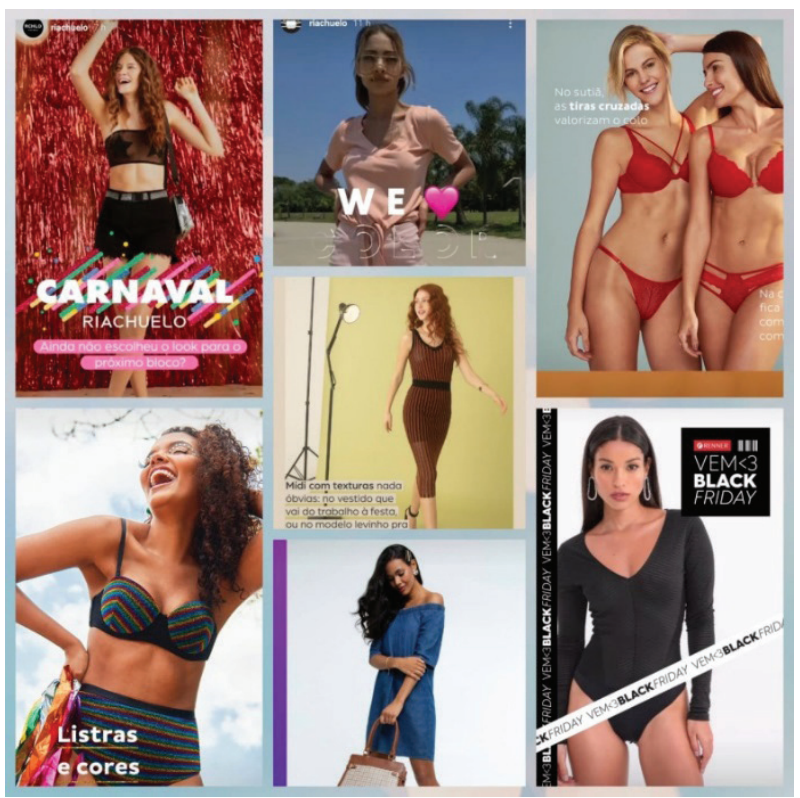

Figura 1: Peças publicitárias das lojas de departamento CEA, Marisa, Renner e Riachuelo

Fonte: Pesquisa de campo (Instagram, 2020).

A Figura 1 revela que as propagandas das lojas de departamento ainda fazem uso de mulheres magras e altas como perfil para promover as roupas, ou seja, tais traços são propagados na mídia e difundem um corpo ideal e um padrão como socialmente aceitável para as mulheres, o que interfere na representação do feminino (CASTRO, 2004; SIQUEIRA; FARIA, 2007; MACHADO; 
PEREIRA, 2010; CASTRO; PRADO, 2012; HEINZELMAN et al., 2012). Tal padrão parece de certa forma homogênea, mas as pessoas são plurais. Cada sujeito possui suas peculiaridades que fazem de cada indivíduo um ser único. Muito embora algumas peças publicitárias apresentem mulheres com perfis distintos, inclusive, outros modelos têm sido apresentados ao público hoje em dia, a maioria das modelos ainda segue o mesmo padrão.

Tabela 2: Frequência do sentimento de representatividade através das propagandas de roupa feminina

\begin{tabular}{l|l|l|l}
\hline & Frequência & $\begin{array}{l}\text { Porcentagem } \\
\text { Válida }\end{array}$ & $\begin{array}{l}\text { Porcentagem } \\
\text { acumulativa }\end{array}$ \\
\hline \multirow{3}{*}{$\begin{array}{l}\text { Nunca } \\
\text { Raramente } \\
\text { Às vezes } \\
\begin{array}{l}\text { Quase Sempre } \\
\text { Sempre } \\
\text { Total }\end{array}\end{array}$} & 25 & 13,8 & 13,8 \\
\cline { 2 - 4 } & 58 & 32,0 & 45,9 \\
\cline { 2 - 4 } & 78 & 43,1 & 88,9 \\
\cline { 2 - 4 } & 17 & 9,4 & 98,3 \\
\cline { 2 - 4 } & 181 & 1,7 & 100,0 \\
\hline
\end{tabular}

Fonte: Pesquisa de campo, 2020.

Se se observar o número de mulheres que não se sentem representadas nas propagandas de roupa feminina (as que optaram por nunca, raramente ou às vezes), esse número chega a 161 mulheres (88,9\% da amostra), conforme pode ser observado na Tabela 2. Já com relação àquelas que se sentem estimuladas a comprar através das propagandas, 141 mulheres responderam nunca, raramente ou às vezes, ou seja, 77,90\% da amostra (Tabela 3). A representação da mulher utilizada pela mídia em propagandas e peças publicitárias interfere diretamente na construção da sua identidade feminina, pois, os papéis atribuídos à mulher e ao homem são construídos pela cultura e pela sociedade que estão inseridos (CABRAL; DÍAZ, 1998). Então, os padrões de beleza e comportamento apresentados pelo marketing, que refletem a sociedade machista e patriarcal que essas mulheres estão inseridas, fazem com que seja imposta à mulher a forma como ela deve ser e agir, o que impacta diretamente na construção do ser mulher. Para que essa mulher se veja indepen- 
dente das imposições dos padrões e papéis a qual são submetidas, demanda tempo, visto que a "receita de mulher perfeita" está pronta e acabada e todas devem seguir.

Tabela 3: Frequência de compra estimulada pelas

propagandas de roupa feminina

\begin{tabular}{llll}
\hline & Frequência & $\begin{array}{l}\text { Porcentagem } \\
\text { Válida }\end{array}$ & $\begin{array}{l}\text { Porcentagem } \\
\text { acumulativa }\end{array}$ \\
\hline $\begin{array}{l}\text { Nunca } \\
\text { Raramente }\end{array}$ & 14 & 7,7 & 7,7 \\
Às vezes & 53 & 29,3 & 37,0 \\
Quase Sempre & 74 & 40,9 & 77,9 \\
Sempre & 27 & 14,9 & 92,8 \\
Mais de uma alter- & 11 & 6,1 & 98,9 \\
nativa & 2 & 1,1 & 100,0 \\
Total & 181 & 100,0 & \\
\hline
\end{tabular}

Fonte: Pesquisa de campo, 2020.

Ademais, as mulheres pesquisadas concordam que o marketing influencia a sociedade, a cultura e os padrões de beleza. A soma das que concordam ou concordam totalmente chega a $80,11 \%$ do total da amostra (Gráfico1). Tal percepção corrobora o debate proposto pela literatura que trata da influência do marketing na construção da sociedade nos seus mais diversos aspectos e, sobretudo, o papel do marketing para as relações sociais (VIANNA, 2005; CASTRO; PRADO, 2012; ZAMBONI, 2013). Os dados nos apontam que 85,4\% da amostra concordam ou concordam totalmente que a cultura, a sociedade e os padrões de beleza em vigência interferem nas escolhas mercadológicas das empresas assim como o marketing também se adapta ao ambiente e é influenciado pela sociedade e cultura da qual o indivíduo faz parte (MORAES et al., 2014; CAVALCANTI et al., 2016). Desse modo, os valores e discursos propagados pela mídia serão o reflexo dessa sociedade, por isso, ainda vemos tantas peças publicitárias sexistas e misóginas nas mídias. 


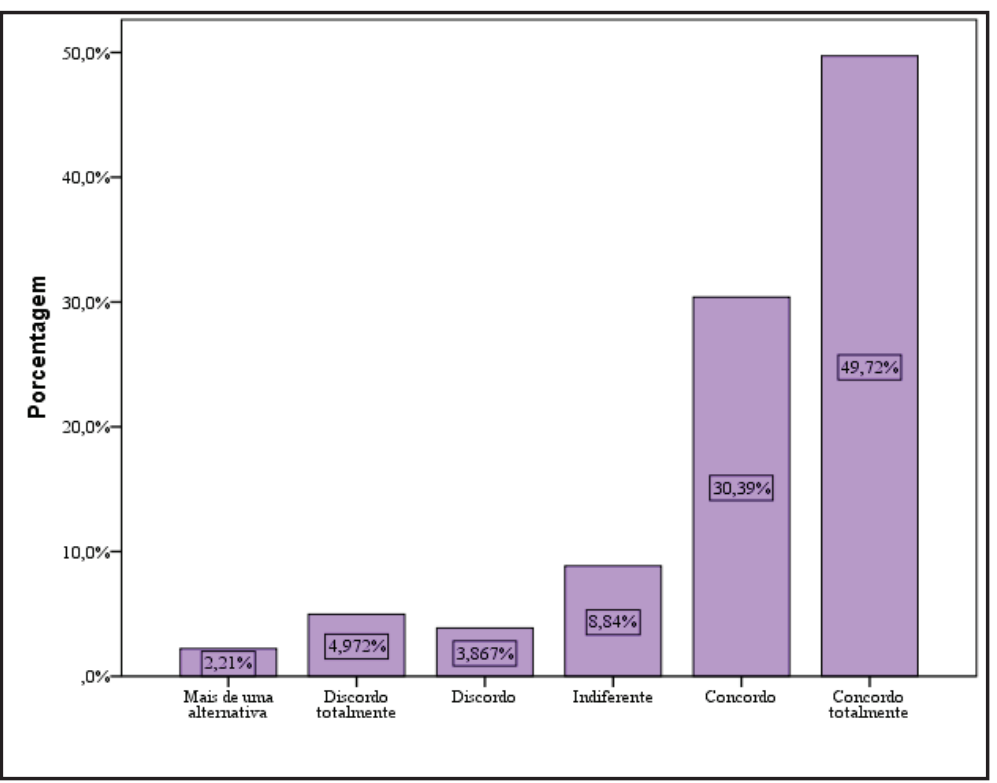

Gráfico 1: Grau de concordância de que a mídia representa, na contemporaneidade, um instrumento importante para transmissão de mensagens sobre padrões de comportamento e imagens de beleza considerados ideais

Fonte: Pesquisa de campo, 2020.

O perfil das modelos, mesmo que variando de acordo com o padrão pré-estabelecido, ainda aparece em algumas peças publicitárias. As lojas divulgam que sua moda é dirigida para mulheres de todos os corpos, entretanto, observando as peças publicitárias, o "padrão de beleza" das mulheres ainda se perpetua. Mais uma vez, o resultado da pesquisa de campo aponta que as mulheres pesquisadas não se sentem representadas pelas propagandas que difundem mulheres brancas, altas, magras, cabelos longos e lisos como corpo ideal (CASTRO, 2004; SIQUEIRA; FARIA, 2007; MACHADO; PEREIRA, 2010; CASTRO; PRADO, 2012; HEINZELMAN et al., 2012). Demanda tempo para se mudar hábitos, então, no decorrer das peças publicitárias analisadas, podemos verificar que já são utilizados modelos com corpos diversos, que nos mostram 
corpos femininos mais próximos da maioria das brasileiras e que não se adequam exatamente ao padrão estabelecido.

Perguntadas se as propagandas difundem como corpo ideal o modelo europeu de mulheres brancas, altas, magras, com cabelos longos e lisos, 76,24\% concordam ou concordam totalmente que esse padrão de "corpo ideal" é apresentado nas propagandas (Gráfico 2). Os dados apresentados confirmam o debate da literatura especializada, de que o padrão de corpo ideal amplamente divulgado pela mídia constrói a relação da mulher com o seu corpo.

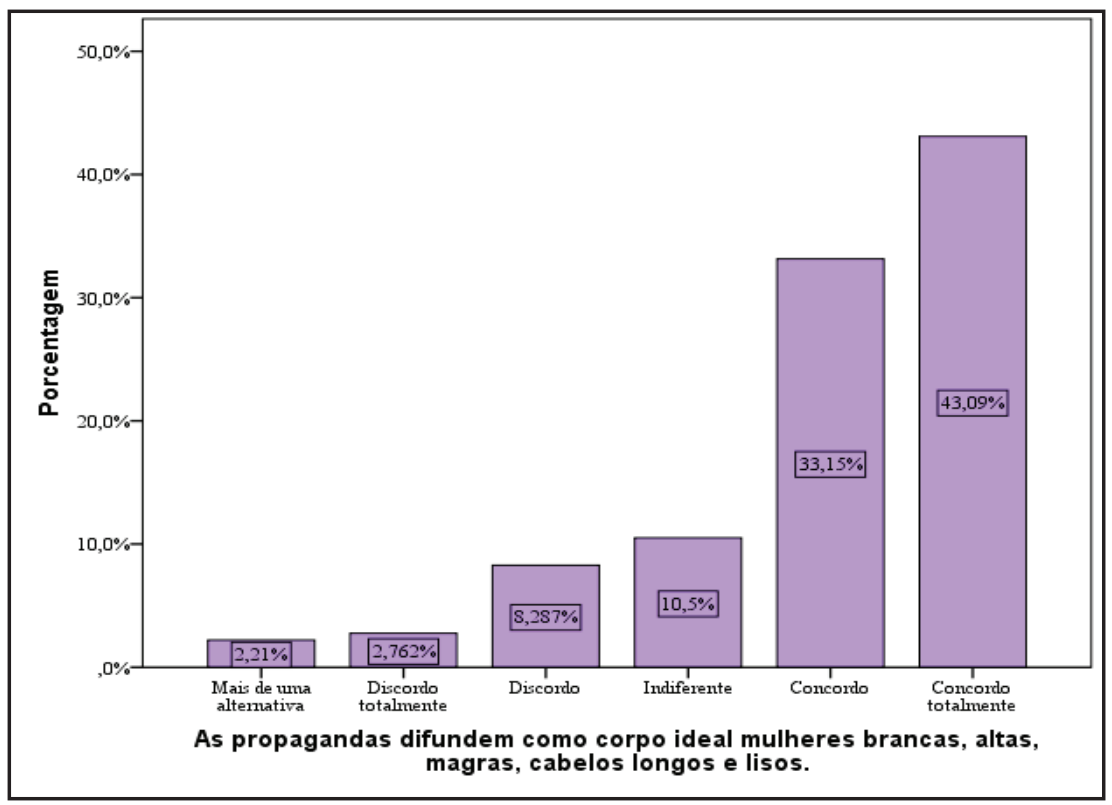

Gráfico 2: Grau de concordância se as propagandas difundem o estereótipo de corpo ideal

Fonte: Pesquisa de campo, 2020.

Questionadas se a mulher é tratada como objeto nas propagadas e peças publicitárias, $84,53 \%$ das participantes responderam que concordam ou concordam totalmente que as mulheres ainda são vistas como objeto para promoção dos produtos das marcas. Isso se aplica não somente às peças publicitárias para roupas femininas, pois, tal comportamento se repete em outros segmentos de 
mercado, como nas propagandas para venda de automóveis que trazem modelos femininas para atrair o público masculino. Esse resultado tem estreita relação com o debate proposto por Castro e Padro (2012), que discorrem sobre como a publicidade se utiliza do corpo feminino para conquistar a atenção do público, tornando-o um objeto. De acordo com Machado (2009), o corpo é tratado como objeto em transformação e moldado para atender as demandas da sociedade. Para Machado e Pereira (2010), o corpo se torna objeto de valor, tratado, desse modo, como mercadoria a ser consumida.

Segundo Sales et al. (2014), a mídia representa um importante instrumento para transmissão de mensagens, sejam elas comportamentais ou de imagens de beleza consideradas ideais. Deste modo, assim como a mídia determina o que deve ser consumido, as propagandas de roupa feminina também o fazem. As modelos usam as roupas para vendê-las, então, se tais modelos correspondem a um determinado padrão aceito pela sociedade tido como ideal, consequentemente, as consumidoras irão relacionar o corpo da modelo à roupa que, naquela modelo se encaixou perfeitamente, mas pode não acontecer o mesmo com a consumidora. Daí se estabelece um conflito por que essa mulher consumidora vai desejar se adequar a modelo para usar a roupa. Mas, se essa mulher se sente representada nas propagandas e peças publicitárias sua relação com seu corpo se modifica.

Ao se estabelecer uma relação entre a instrumentalização do corpo feminino como objeto com o discurso publicitário de que leva a crer que a mulher é tratada como objeto, Zamboni (2013) defende que os discursos publicitários reforçam os padrões estabelecidos. Tanto a publicidade quanto o discurso publicitário, na perspectiva das participantes do estudo, tratam as mulheres como objeto, visto que das 181, 153 respostas concordam ou concordam totalmente com tal afirmação. Mesmo com todos os avanços na busca por igualdade entre mulheres e homens, vemos que quando o assunto é objetificação do corpo feminino o termo ainda se encontra presente nas peças publicitárias e propagandas veiculadas nos meios de comunicação.

A construção do sujeito depende de fatores externos a ele, que são históricos, culturais e sociais. Deste modo, quando se questionou das informantes o grau de concordância a respeito de que o 
corpo é algo que o indivíduo constrói, que comunica quem ele é e o posiciona na sociedade, a soma entre as que concordam ou concordam totalmente chega a 153 mulheres de um total de 181, o que demonstra a relação da teoria com a pesquisa empírica. Segundo Dourado et al. (2018), a beleza depende da visão de mundo do indivíduo, que é construída através das experiências adquiridas no decorrer da vida e sofre interferência da sociedade e cultura da qual o sujeito está inserido.

A sociedade a qual estamos inseridos possui valores patriarcais e machistas que querem ditar regras e normas que as mulheres devem seguir. Cabe às mulheres o papel de ser protagonista da sua história, na luta pela igualdade e tratamento que leve em consideração seus desejos e necessidades. Esse pensamento começou a ser construído na primeira onda do movimento feminista, ainda no século XIX, quando as lutas começaram, mas ainda tem uma longa trajetória a percorrer. A terceira onda do movimento feminista teve início na década de 1990, no século XX e até hoje busca a legitimação da mulher na sociedade (LOURO, 1997). Muito embora a mulher seja maioria na sociedade brasileira, ainda se tem muito a conquistar e muitos tabus a quebrar.

\section{A Imagem e Beleza Feminina}

Na divisão patriarcal da sociedade, coube a mulher o espaço privado, ou seja, foi imposto a ela o papel de cuidadora da casa e da família, dona de casa, esposa e mãe (CAIXETA, 2004) e todas as atividades domésticas ficariam, por conseguinte, a cargo dela. Essa mulher deveria ser discreta e submissa ao homem para ser aceita e considerada ideal. $\mathrm{O}$ esperado para a mulher era nascer, crescer e se casar, tornando-se, então, dona de casa, esposa e, posteriormente, mãe. A mulher não podia estudar, muito menos expor suas opiniões. Essa era a imagem que a sociedade pregava. Entretanto, a imagem feminina se modificou através dos tempos. As percepções das participantes da presente pesquisa e as reflexões acerca da imagem feminina na mídia serão apresentadas no decorrer deste tópico.

A forma como a imagem da mulher é representada pela mídia interfere diretamente na relação da mulher com a sua imagem e o seu corpo. A construção da identidade feminina e, então, da imagem 
que essa mulher representa na sociedade é a composição de vivências e experiências de vida. Tudo o que somos é uma construção do meio, desta maneira, recebemos também influência das mídias nas nossas relações sociais.

O padrão de beleza está se modificando assim como a sociedade. Durante a coleta das peças publicitárias, direcionadas para o público feminino, podemos observar que o perfil das modelos variou entre modelos negras, com cabelos cacheados e crespos, modelos com corpos tidos como "normais", conforme podemos observar na Figura 2. A Figura 2 nos mostra que as peças publicitárias estão buscando diversificar suas modelos para atender a expectativa e os vários tipos de corpos de suas consumidoras, pois, as mulheres reais não são basicamente altas, magras e com cabelos compridos, em outras palavras, são compostas por mulheres com alta ou baixa estatura, magras ou acima do peso, de peles de diversas cores e tons (negras, pardas, amarelas, indígenas), com cabelos lisos, cacheados, crespos ou ondulados, ou seja, são diversificadas e todas elas devem ser representadas, visto que essas mulheres também são consumidoras. De acordo com o IBGE (2019), na Pesquisa Nacional por Amostra de Domicílios entre 2012-2019, as pessoas que se declaram pardas representam a maioria da população $(46,8 \%)$, seguida dos que se declaram brancas (42,7\%), pretas, indígenas e amarelas $(11,6 \%)$. E essa imagem representada pela mídia deva influenciar positivamente as futuras gerações que irão aprender que para ser bonito não precisa ser magro ou seguir determinado padrão. $\mathrm{O}$ marketing deve fazer uso da diversidade, buscando compreender os diversos indivíduos que constroem sua identidade através da sociedade, da cultura e da sua percepção de mundo. 


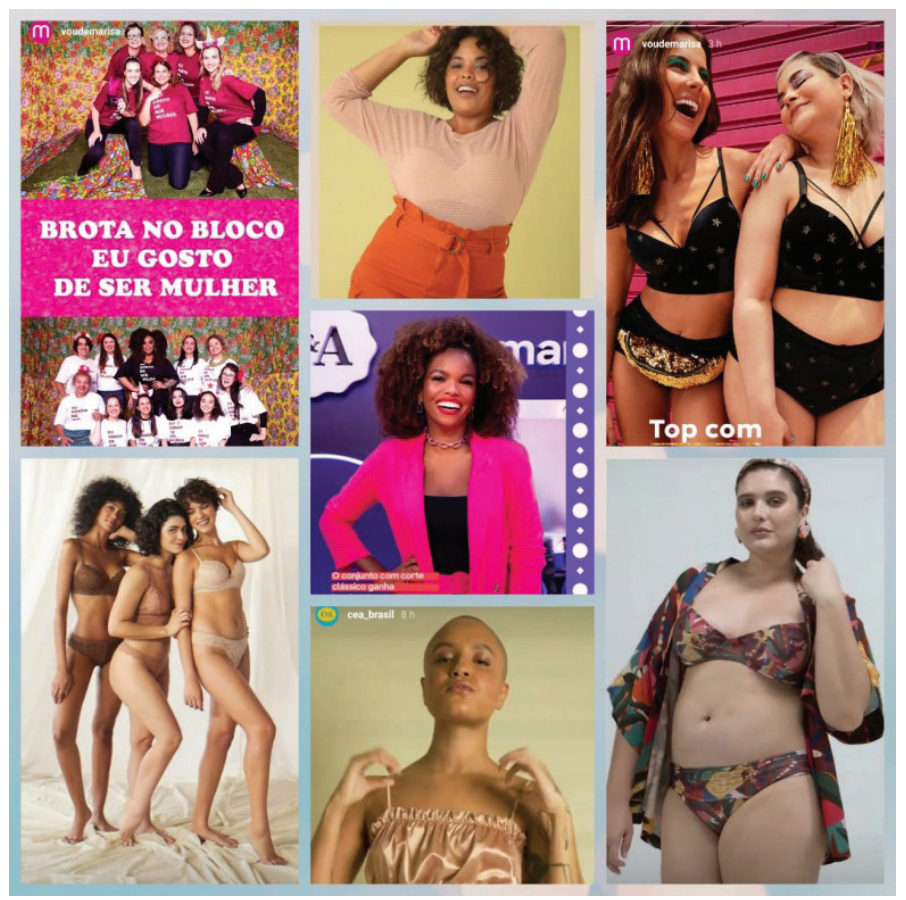

Figura 2: Peças publicitárias das lojas de departamento CEA, Marisa, Renner e Riachuelo

Fonte: Pesquisa de campo, (Instagram, 2020).

A imagem e representação feminina está se modificando, como podemos observar na Figura 2. Demanda muito tempo para que os padrões de beleza, até então tidos como ideais, se modifiquem e se adequem aos anseios da sociedade, em especial, às mulheres. $\mathrm{O}$ corpo é objeto de desejo e cobiça dos homens. Para agradá-los, devem ser magros e curvilíneos, com todas as proporções desejáveis, mas a presente pesquisa revelou que esse não é exatamente o pensamento das mulheres, uma vez que 141 mulheres, de um total de 181, responderam que concordam ou concordam totalmente que o padrão de beleza é construído por uma sociedade machista e patriarcal.

A maioria das participantes $(77,9 \%)$ concordam ou concordam totalmente que o ideal de beleza atual foi construído por uma sociedade patriarcal e machista. Percebe-se que o tema padrão de beleza ainda é presente em nossa sociedade como a construção de mode- 
los designados para atender os desejos dos homens. No entanto, a imagem corporal foi se modificando no decorrer dos anos. Antes o corpo roliço era a representação da saúde e o ideal de beleza. A partir do início do século $\mathrm{XX}$, esse padrão foi se alterando e o corpo magro começou a ser apontado como o ideal, a imagem da mulher passa a ser magra e alta (DOURADO et al., 2018). Desse modo, percebe-se que a imagem corporal foi se modificando no decorrer dos anos e essa imagem não foi construída necessariamente pelas mulheres, como podemos observar na percepção das mulheres que colaboraram com esta pesquisa.

Quando questionadas se o corpo magro é o ideal de beleza, $67,96 \%$ discordam ou discordam totalmente que este é seu ideal de beleza. Os dados demostram que as mulheres não concordam com o padrão estabelecido pela atual sociedade. Então, os números permitem inferir que a representação da imagem da mulher na mídia é uma construção masculina, para atender as suas necessidades e desejos na idealização do corpo feminino, dado que a maioria das respostas contraria o que vem se estabelecendo como corpo ideal.

Verifica-se que a maior parte da amostra (123 mulheres de um total de 181) nos revela que a concepção de beleza e ideal de corpo está se modificando, pelo menos do ponto de vista feminino e que as mulheres não concordam que o corpo magro seja o ideal de beleza. Da mesma forma, veem que cabe a mulher decidir se segue ou não o padrão de beleza estabelecido. A relação da beleza estética com o corpo magro ganha força no século XX (BARBOSA; MATOS; COSTA, 2011). O corpo é utilizado para se comunicar e se posicionar perante a sociedade (MACHADO; PEREIRA, 2010). Dessa forma, através do corpo do indivíduo podemos relacioná-lo com determinada cultura ou sociedade.

Os padrões de beleza atuais, estabelecidos pela sociedade para as mulheres, são inatingíveis. Se contarmos que cada corpo tem parâmetros diferentes e que as mulheres brasileiras têm um biotipo que difere daquele pregado como ideal, não seguir os padrões sociais de beleza não tem relação com a beleza feminina, pois, 70,17\% da amostra discordam ou discordam totalmente que não seguir os padrões sociais de beleza é negar a norma social de beleza feminina. A mulher não deixa de ser bonita por não se adequar aos padrões 
pré-estabelecidos de beleza ideal. Segundo Vianna (2005), querer que todas as mulheres se enquadrem no padrão de beleza imposto, sem levar em consideração que todas têm corpos distintos, é uma forma de violência. Para Aguilera, Branco e Prado (2016), o padrão de beleza feminina se modifica a depender de diversos fatores, porém, o que sempre acontece é que desde a Antiguidade o corpo feminino é descrito por padrões e normas.

A relação entre o sentir-se bonita como mulher e a necessidade de se enquadrar nos padrões de beleza estabelecidos para ser aceita remete ao debate propostos por Dourado et al. (2018) de que a beleza depende da visão de mundo do indivíduo. Dessa forma, 61,33\% das mulheres discordam ou discordam totalmente de que precisam se enquadrar nos padrões pré-estabelecidos para serem aceitas pela sociedade. Então, percebe-se que essas mulheres conseguem se sentir bonitas dentro da sociedade que estão inseridas mesmo não se adequando ao padrão ideal de beleza pregado pela mídia.

As respondentes nos mostram que a mulher consegue se sentir bonita, quase sempre e sempre $(61,33 \%)$, mesmo diante de tantas imposições, que têm como berço uma sociedade patriarcal e machista. Embora a pressão seja intensa, a mulher tenta se desvencilhar de estigmas e cobranças que lhe são impostas. Esse resultado remete à definição proposta por Wolf (1992) de que a beleza é um mito, que não foi criado pelas mulheres, mas sim, pelos homens, que buscam impor à mulher o que é belo.

O marketing ajuda a reforçar esse mito e influencia o consumo e as relações sociais e, do mesmo modo, ao divulgar e propagar imagens interfere na representação dos corpos femininos. Deste modo, a forma como os corpos são apresentados influencia diretamente na representação de como a mulher se reconhece. A Figura 2 revela que as lojas estão diversificando os modelos de corpos que fazem a propaganda de suas roupas em suas peças publicitárias. Com isso, o padrão tido como ideal está se modificando, pois, os corpos são diversos e bonitos cada um à sua maneira. A Figura 2 nos mostra que a percepção das lojas vem se modificando, ao buscar representar outras mulheres que não somente aquelas que se enquadravam no padrão branca, magra e alta, imposto pela mídia. Ao que parece, as expectativas do público feminino estão sendo atendidas. 


\section{CONSIDERAÇõES FINAIS}

A imagem atribuída ao corpo, e seu padrão considerado como ideal, se modifica de acordo com a história, a cultura e as relações sociais que o indivíduo trava e é construída desde o nascimento até o fim da vida de uma pessoa. Tal padrão é construído através das vivências e experiência que cada um constrói para si, pois, cada experiência será percebida de uma forma diferente a depender de quem a vive.

A representação desse corpo, perante a sociedade, expressa quem ele é, de que forma ele se identifica com a sociedade que está inserida e o que ele capta dela. Essa representação nos é apresentada na relação com o outro e também através da mídia, quando temos acesso a propagandas e peças publicitárias, divulgadas nos mais diversos meios de comunicação. A informação hoje nos chega com uma rapidez que não imaginávamos há 50 ou 60 anos atrás. O que acontece do outro lado do globo em fração de segundos já se torna público em todo o território nacional graças ao avanço tecnológico. A velocidade e propagação de informações que interferem na representação do corpo e da imagem do feminino também são sentidas por todos e todas imediatamente hoje em dia.

A relação da imagem divulgada na mídia e a imagem real, por vezes, são distantes e conflitantes, uma vez que são utilizadas diversas ferramentas para modificar a imagem e transformá-la em um modelo ditado como ideal a um padrão proposto. Nesse aspecto, o marketing tem papel fundamental na construção desses padrões de corpo e de beleza que nos é apresentado. O marketing divulga o que socialmente é aceito para os corpos femininos, a forma como este corpo deve ser e deve se posicionar para a sociedade.

Para conhecer um pouco mais sobre esse tema, 181 mulheres se propuseram a colaborar com a presente pesquisa, contribuindo, assim, para que possamos entender um pouco como o marketing influencia a sua relação com o corpo e a representação social da mulher.

O perfil das participantes se tornou relativamente homogêneo no que diz respeito ao nível de escolaridade, visto que $91,71 \%$ das informantes possuem ensino superior incompleto, completo ou pós-graduação. Dessa forma, a percepção de beleza aqui apresentada é de um grupo de mulheres com uma escolaridade semelhante. Se a 
amostra fosse mais heterogênea talvez os resultados fossem distintos logo que se pressupõe que o grau de escolaridade interfere na percepção do sujeito quanto a influência das propagandas publicitárias e até mesmo da criticidade e autonomia de opinião. Muito embora o presente trabalho tenha dirigido seu foco para mulheres jovens, na amostra estudada, predominou uma parcela de mulheres entre 20 e 25 anos, seguida pelas que têm entre 36 e 44 anos. Com relação aos grupos étnicos, houve predomínio daquelas que se declararam pardas. Quanto ao estado civil, 59,12\% estão solteiras. Tendo em vista a adoção do snowball, a coleta se estendeu para além da cidade de Vitória da Conquista, pois 20,99\% das respondentes são de outras cidades. Entretanto, a maioria das participantes reside na cidade de Vitória da Conquista, região sudoeste da Bahia.

Quando questionadas a respeito do que sentem ao ver a representação da mulher nas propagandas de moda feminina, a maioria das mulheres se diz indiferente, seguida pelas que se sentem desconfortáveis. Pode-se observar que a parcela que se sente desconfortável é mais jovem. A grande maioria nunca, raramente ou às vezes se sente representada nas propagandas. Do mesmo modo, as que não se sentem estimuladas a comprar pelas propagandas de roupa feminina chegam a $77,9 \%$.

A mídia desempenha importante papel na divulgação e na construção de padrões de beleza que, por conseguinte, interferem na aceitação daquilo que é construído como ideal. Dessa maneira, $80,11 \%$ da amostra concordam ou concordam totalmente que o marketing é um importante instrumento de transmissão de mensagens sobre padrão de comportamento e de imagens de beleza considerados ideais. Se a cultura, a sociedade e os padrões de beleza são influenciados pelo marketing, 85,7\% concordam ou concordam totalmente que o marketing influencia diretamente na concepção de conceitos de beleza e de padrões que devem ser aceitos. Boa parte das entrevistadas concorda que as propagandas difundem modelos ou padrões de corpo ideal a serem seguidos com a predominância de mulheres brancas, altas, magras, cabelos longos e lisos. A maioria das mulheres concorda que o corpo feminino é instrumentalizado nas peças publicitárias e, por vezes, tratado como objeto para aten- 
der a demanda da mídia na promoção de seus produtos e até mesmo apresentar determinado produto.

Levando-se em conta que a definição de beleza feminina é resultado de uma construção social e, por conseguinte, influenciada pelos preceitos de uma sociedade predominantemente machista e patriarcal, quando foram questionadas a respeito do significado de beleza, 77,9\% disseram que o ideal de beleza foi construído por homens para atender as suas necessidades e desejos, inclusive, 67,96\% da amostra discordam que o corpo magro é o ideal de beleza. Esse resultado revela que o padrão socialmente aceito para os corpos femininos não atende a vontade da mulher, mas sim da sociedade. Vale salientar que é possível que o grau de escolaridade da amostra tenha influenciado nesse resultado pois, indivíduos com nível superior costumam ser mais críticos e questionadores, afinal esse é o papel da educação.

Para as mulheres que participaram desta pesquisa, cabe à mulher seguir ou não os padrões impostos a ela, tendo em vista que a mulher deve tomar as decisões que achar conveniente para si e para seu corpo. Os padrões de beleza impostos pela mídia dificilmente podem ser seguidos pelas mulheres brasileiras, dado a composição étnica da população. No entanto, 70,17\% discordam ou discordam totalmente que negar a norma social de beleza feminina imposta pelos meios de comunicação não significa deixar de ser bonita ou feminina. Quando questionadas sobre a beleza, o resultado reforça que a relação com o corpo feminino diz respeito tão e somente à mulher, portanto, $80,97 \%$ das mulheres responderam que a beleza depende de como se sentem em seu interior e como se veem.

Considerando que $61,33 \%$ da amostra discordam ou discordam totalmente que para serem aceitas pela sociedade as mulheres devem estar dentro dos padrões de beleza, é possível afirmar que as empresas ainda se utilizam de modelos considerados como padrão, no entanto, suas peças publicitárias e propagandas estão se modificando, uma vez que para ser feminina e se sentir mulher não é necessário atender as normas vigentes. Para tanto, quando perguntadas se se acham bonitas, as que responderam quase sempre e sempre chegam a $61,3 \%$. 
A presente pesquisa enfrentou diversos infortúnios no decorrer de sua execução. A coleta de dados foi interrompida, ainda em seu início, devido à suspensão das atividades de ensino, pesquisa e extensão em decorrência da pandemia do novo Coronavírus COVID-19, entre o período de 19 de março a 18 de outubro, o que dificultou a aplicação dos questionários e a intenção de realização de entrevistas para entender melhor o fenômeno estudado a partir da fala das mulheres. Do mesmo modo, fomos limitados no que diz respeito à amostra, que ficou um tanto quanto homogênea em se tratando do grau de escolaridade. Embora o questionário tenha sido enviado para o maior número possível de mulheres, elas repassaram para outras mulheres de seus grupos sociais que, por sua vez, tinham um perfil semelhante em se tratando de grau de instrução.

O tema proposto, a influência no marketing na construção dos padrões de beleza feminino, buscou compreender esse universo que ainda é pouco explorado dentro do marketing. Esta pesquisa pode ser continuada com uma amostra maior e com a busca da estratificação de faixa etária e escolaridade. Desta forma, pode-se conhecer um perfil ainda mais diversos e heterogêneo do universo feminino.

\section{REFERÊNCIAS}

AGUILERA, Juliana Cristina P.; BRANCO, Beatriz P.; PRADO, Magaly. Minha Beleza é Minha: a Influência Exercida pelas Mídias sobre a Imagem Feminina. In: INTERCOM, 39, São Paulo, 2016. Anais... São Paulo: ECA/USP, 2016. Disponível em: < https://portalintercom.org. br/anais/nacional2016/lista_area_RT07.htm>. Acesso em: 13 fev. 2020.

APPOLINÁRIO, Fábio. Metodologia da Ciência: Filosofia e Prática da Pesquisa. $2^{\underline{a}}$ edição. São Paulo: Cengage Learning, 2012.

ALVES, José Eustáquio D.; CAVENAGUI, Suzana Marta. Indicadores de Desigualdade de Gênero no Brasil. Mediações, Londrina, v. 17, n. 2, p. 83-105, jul./dez. 2012. Disponível em: < http://www.uel.br/revistas/uel/index.php/mediacoes/article/view/16472>. Acesso em: 02 nov. 2020.

BARBOSA, Maria Raquel; MATOS, Paula M.; COSTA, Maria Emília. Um Olhar Sobre o Corpo: o Corpo Ontem e Hoje. Psicologia \& Sociedade, Florianópolis, v. 23, n. 1, p. 24-34, 2011. Disponível em: <http://www.scielo.br/pdf/psoc/v23n1/a04v23n1.pdf>. Acesso em: 20 nov. 2019.

BARBOZA, Heloisa Helena G.; ALMEIDA JÚNIOR, Vitor A. (Des)Igualdade de Gênero: Restrições à Autonomia da Mulher. Pensar, Fortaleza, v. 22, n. 1, p. 240-271, jan./abr. 2017. Disponível em: <https://periodicos.unifor.br/rpen/article/view/5409>. Acesso em: 01 out. 2019. 
BARROS, Daniela D. Imagem Corporal: a Descoberta de si mesmo. História, Ciências, Saúde - Manguinhos, Rio de Janeiro, v. 12, n. 2, p. 547-554, mai./ago. 2005. Disponível em: < https://www.scielo.br/scielo.php?pid=S0104-59702005000200020\&script=sci_abstract\&tlng=pt $>$. Acesso em: 21 out. 2020.

BEAUVOIR, Simone de. O Segundo Sexo. A Experiência Vivida. 2 ${ }^{\mathrm{a}}$ Edição. Difusão Européia do Livro. 1980.

BERGER, Peter. L; LUCKMANN, Thomas. A Construção Social da Realidade: Tratado de Sociologia do Conhecimento. 24ํㅜ ed. Petrópolis: Vozes, 2004.

BORGES, Carolina C. Mudanças nas Trajetórias de Vida e Identidades de Mulheres na Contemporaneidade. Psicologia em Estudo, Maringá, v. 18, n. 1, p. 71-81, jan./mar. 2013. Disponível em: <http://www.scielo.br/pdf/pe/v18n1/v18n1a07.pdf>. Acesso em: 01 out. 2019.

BRASIL. Constituição da República Federativa do Brasil. In: MEDAUAR, O. (Org.) Coletânea de Legislação Administrativa, Constituição Federal. 13ํe edição. São Paulo: Editora Revista dos Tribunais, 2013.

CABRAL, Francisco; DÍAZ, Margarita. Relações de Gênero. In: SECRETARIA MUNICIPAL DE EDUCAÇÃO DE BELO HORIZONTE: Fundação ODEBRECHT. Cadernos Afetividade e Sexualidade na Educação: um Novo Olhar. Belo Horizonte: Gráfica e Editora Rona Ltda., 1998, p. 142-150.

CAIXETA, Juliana Eugênia. Identidade Feminina - Um Conceito Complexo. Paidéia, Ribeirão Preto, v. 14, n. 28, p. 211-220, 2004. Disponível em: <http://www.scielo.br/pdf/paideia/ v14n28/10.pdf>. Acesso em: 01 out. 2019.

CASTRO, Ana Lúcia. Culto ao Corpo e Sociedade: a Mídia, Cultura de Consumo e Estilo de Vida. 2001. 183 f. Tese (Doutorado em Ciências Sociais) - Universidade de Campinas, Campinas.

CASTRO, Ana Lúcia. Corpo, Consumo e Mídia. Comunicação, Mídia e Consumo. São Paulo, v. 1, n. 1, p. 1-16, 2004. Disponível em: <http://revistacmc.espm.br/index.php/revistacmc/ article/view/2>. Acesso em: 18 nov. 2019.

CASTRO, Ana Lúcia; PRADO, Juliana. Corpo e Identidades Femininas: a Intermediação da Mídia. Revista Estudos de Sociologia, Araraquara, v. 17, n. 32, p. 241-259, 2012. Disponível em: <https://periodicos.fclar.unesp.br/estudos/article/view/4937>. Acesso em: 17 nov. 2019.

CAVALCANTI, Hellen Taynan da Silva et al. Marketing e Diversidade: Prazer, Eu Existo. Diálogo, Canoas, no 32, p. 203-224, ago. 2016. Disponível em: <https://revistas.unilasalle.edu. br/index.php/Dialogo/article/view/2183>. Acesso em: 08 out. 2019.

COBRA, Marcos. Administração de Marketing no Brasil. $3^{\underline{a}}$ edição. Rio de Janeiro: Elsevier, 2009.

COSTA, Ana Alice A. As Donas no Poder. Mulher e Política na Bahia. Salvador: NEIM/ UFBA - Assembléia Legislativa da Bahia, 1998.

DEMO, Pedro. Introdução à Metodologia da Ciência. 2ª edição. São Paulo: Atlas, 1985

DOURADO, Cláudia S. et al. Corpo, Cultura e Significado. Journal of Human Growth and Development. São Paulo, v. 28, n. 2, p. 206-212, 2018. Disponível em: <http://www.journals. usp.br/jhgd/article/view/147240>. Acesso em: 17 nov. 2019. 
FIORANI, Mauro. Padrões de Corpo e Moda. 2007. 145 f. Dissertação (Mestrado em Moda, Cultura e Arte) - Centro Universitário SENAC - São Paulo.

GARCIA, Wilton. Consumo e Diversidade Cultural/Sexual: Investigações Interdisciplinares. Signos do Consumo. São Paulo, v. 1, n. 2, p. 214-225, jan./jun. 2009. Disponível em: < http:// www.revistas.usp.br/signosdoconsumo/article/view/42776>. Acesso em: 21 out. 2020.

GIL, Antonio Carlos. Como Elaborar um Projeto de Pesquisa. $4^{\mathrm{a}}$ edição. São Paulo: Atlas, 2002 GIL, Antonio Carlos. Métodos e Técnicas de Pesquisa. 6ª edição. São Paulo: Atlas, 2008.

HEINZELMAN, Fernanda. L. et al. Corpos em Revista: a Construção de Padrões de Beleza na Vogue Brasil. Psicologia em Revista, Belo Horizonte, v. 18, n. 3, p. 470-488, 2012. Disponível em: <http://periodicos.pucminas.br/index.php/psicologiaemrevista/article/view/P.1678-9563. 2012v18n3p470>. Acesso em: 17 nov. 2019.

IBGE - Instituto Brasileiro de Geografia e Estatística. Cor ou Raça. 2019. Disponível em: $<$ https://educa.ibge.gov.br/jovens/conheca-o-brasil/populacao/18319-cor-ou-raca.html\#: :tex$\mathrm{t}=$ De $\% 20$ acordo $\% 20$ com $\% 20$ dados $\% 20$ da, $1 \% 25 \% 20$ como $\% 20$ amarelos $\% 20$ ou $\% 20$ ind $\%$ C $\%$ ADgenas>. Acesso em: 07 dez. 2020.

KOTLER, Philip; ARMSTRONG, Gary. Princípios de Marketing. 12º edição. São Paulo: Pearson Prentice Hall, 2007.

LAKATOS, Eva Maria; MARCONI, Marina A. Fundamentos de Metodologia Científica. $5^{\text {a }}$ edição. São Paulo: Atlas, 2003.

LIMEIRA. Tania Maria V. Comportamento do Consumidor. São Paulo: Saraiva, 2008.

LOURO, Guacira L. Gênero, Sexualidade e Educação. Uma Perspectiva Pós-Estruturalista. Petrópolis, RJ: Vozes, 1997.

MACHADO, Maíra V. Espelho, Espelho Meu, Quem Sou Eu? Consumo Estético e a Construção da Identidade da Mulher. 2009. 136 f. Dissertação (Mestrado Profissional em Administração) - Fundação Instituto Capixaba de Pesquisa em Contabilidade, Economia e Finanças - FUCAPE, Vitória.

MACHADO, Maíra V.; PEREIRA, Severino Joaquim N. Espelho, Espelho Meu, Quem Sou Eu? Consumo Estético e a Construção da Identidade da Mulher. In: ENCONTRO DE MARKETING DA ANPAD - EMA. 4. Florianópolis, 2010. Anais... Florianópolis: ANPAD, 2010. Disponível em: <http://www.fucape.br/_public/producao_cientifica/2/Maira.pdf >. Acesso em: 17 nov. 2019. MARCON, Fernanda A.; MARCON, Gabriela A.; ROCHA, Rudimar A. Marketing Crítico e Ideologia Feminista na Pós-Modernidade. In: SEMINÁRIOS EM ADMINISTRAÇÃO, 20., São Paulo, 2017. Anais... São Paulo: FEA/USP, 2017. Disponível em: <http://login.semead.com. br/20semead/arquivos/1791.pdf>. Acesso em: 08 out. 2019.

MORAES, Thiago A. et al. Marketing e Diversidade: um Novo Despertar. In: SEMINÁRIOS EM ADMINISTRAÇÃO, 17., São Paulo, 2014. Anais... São Paulo: FEA/USP, 2014. Disponível em: <http://sistema.semead.com.br/17semead/resultado/trabalhosPDF/732.pdf $>$. Acesso em: 08 out. 2019.

ORGANIZAÇÃO DAS NAÇÕES UNIDAS MULHERES BRASIL. Princípios de Empoderamento das Mulheres. ONU Brasil, 2017.

PIZZINATTO, Andrea K.; ACEVEDO, Cláudia R. Representações Femininas na Mídia. In: SEMINÁRIOS EM ADMINISTRAÇÃO, 13., São Paulo, 2010. Anais... São Paulo: FEA/USP, 
2010. Disponível em: <http://sistema.semead.com.br/13semead/resultado/trabalhosPDF/620. pdf $>$. Acesso em: 08 out. 2019.

ROCHA, Ruth; PIRES, Hindenburg S. Minidicionário da Língua Portuguesa. São Paulo: Scipione, 2005.

SAJI, Genilda Sandra M. Gestão da Diversidade no Brasil: Apresentação de um Modelo Brasileiro 2005. 62 f. Dissertação (Mestrado Profissional em Administração) - Escola de Administração de Empresa - Fundação Getúlio Vargas, São Paulo.

SALES, Aline P. et al. "Trabalhada no Glamour": Identidade e Consumo de Beleza por mulheres da Nova Classe Média. In: SEMINÁRIOS EM ADMINISTRAÇÃO, 13, São Paulo, 2014. Anais... São Paulo: FEA/USP, 2014. Disponível em: <http://sistema.semead.com.br/17semead/ resultado/an_resumo.asp?cod_trabalho=1089>. Acesso em: 08 out. 2019.

SANT'ANA, Fernanda S.; BISPO, Letícia C. A Construção Social da Desigualdade entre Gêneros: um Estudo da Percepção de Pais e Mães acerca da Educação dos Filhos. 2017. 102 f. Monografia (Graduação em Psicologia) - Centro Universitário Católico Salesiano Auxilium, Lins, São Paulo.

SANTOS, Juliana A. Desigualdade Social e o Conceito de Gênero. Revista Virtú, Juiz de Fora, v. 1, p. 1-14, 2006. Disponível em: <http://www.ufjf.br/virtu/files/2010/05/artigo-3a7. pdf>. Acesso em: 01 out. 2019.

SIQUEIRA, Denise C. O.; FARIA, Aline A. Corpo, Saúde e Beleza: Representações Sociais nas Revistas Femininas. Comunicação, Mídia e Consumo, São Paulo, v. 4, n. 9, p. 171-188, 2007. Disponível em: http://revistacmc.espm.br/index.php/revistacmc/article/view/95. Acesso em: 18 de novembro de 2019.

SAUERBRONM, João Felipe R.; TONINI, Karla Andrea D.; LODI, Marluce D. F. Um Estudo Sobre os Significados de Consumo Associados ao Corpo Feminino em Peças Publicitárias de Suplementos Alimentares. Revista Eletrônica de Administração - READ, Porto Alegre, edição 68, v. 17, n. 1, jan/abr, p. 01-25, 2011. Disponível em: <https://seer.ufrgs.br/read/article/ view/38697/24802>. Acesso em: 20 nov. 2019.

VIANNA, Cynthia S. M. Da Imagem da Mulher Imposta pela Mídia como uma Violação dos Direitos Humanos. Revista da Faculdade de Direito UFPR, Curitiba, v. 43, n. 0, 2005, p. 1-14. Disponível em: <https://revistas.ufpr.br/direito/article/view/6991/4969>. Acesso em: 27 out. 2019.

VIEIRA, Almir M.; RIVERA, Dario Paulo B. A Hermenêutica no Campo Organizacional: duas possibilidades interpretativistas de pesquisa. Revista Brasileira de Gestão de Negócios, v. 14, n. 44, p. 261-273, 2012.

WOLF, Naomi. O Mito da Beleza - Como as Imagens de Beleza são Usadas Contra as Mulheres. Editora Rocco, Rio de Janeiro, 1992.

ZAMBONI, Júlia S. Para que Serve a Mulher no Anúncio? Um estudo sobre representações de gênero nas imagens publicitárias. 2013. 153 f. Dissertação (Mestrado em Comunicação Social) - Universidade de Brasília, Brasília.

Recebido em: 15-4-2021

Aprovado em: 7-12-2021

Avaliado pelo sistema double blind review.

Disponível em http://mjs.metodista.br/index.php/roc 